\title{
Character Education to Build Personal Learners Tough
}

\author{
Sutarman, Haryono Edi Hermawan, Ahmad \\ LPPM STKIP Arrahmaniyah \\ Jl. Mejid Al-Ittaihad no.8-12 Bojong Pondok Terong Kec. Cipayung Depok
}

\begin{abstract}
Character Education is the education of character, temperament, character, or personality are formed from the internalization of virtues, discipline believed and used as the basis of viewpoint, bepikir, behave and act, the policy in the form of moral values, and norms, such as honest, brave act, trustworthy, respect for others, self-discipline, independent, hard working, creative and innovative. Personal character is a person who can make decisions and are ready to take responsibility for each policy. Character education on students, each character education is the education process aimed at developing values, attitudes, and behaviors radiate a noble character and noble character, a positive value and that should be owned by individuals is charitable pious habits (habits), mandate, anticipatory, well thought, hard work, civilized, dare to do good, responsible, courageous risk, disciplined, and devoted to Allah glory to Him, Indeed this character education should start early, a process that must be done continuously in shaping the character students are formidable.
\end{abstract}

Keywords; Character Education, Learners, Tough

\section{Introduction}

Character education is an effort to build a formidable personal protégé either the inner or outer Character education is higher than on moral education, which always run good habits in all the activities of life (habit.). In Act 20 of 2003 on National Education System states that the National Education National Education serves to develop skills and character development as well as the dignity of the Nation. Has the objective to the development potential of students in order to become a man of character, integrity, faith and devoted to Allah glory to Him. Noble, physically and mentally healthy, knowledgeable, skilled, creative, independent, and become responsible citizens. Try to evaluate the system of learning to produce human character in the search process National Identity in the Indonesian education system, the direction to achieve balance as human beings, have a desire to achieve and therefore the role of schools and teachers as formal education institutions and as a spearhead in the wewujudkan education character. Character education is tough, quality noble, creative, innovative, insightful nationality, intelligent, healthy, disciplined and responsible, and master of science and technology in order to develop the quality of students' character. Must continually improving academic skills and professional and improve the welfare of education personnel, in improving the educational character mapu improve the credibility of the institution itself and continue to empower educational institutions whether formal, non-formal and informal, and should involve all stakeholder, in civilizing values, attitudes, and abilities, as well as increasing the participation of families and communities, supported by adequate infrastructure and qualified.

\section{The problem of Formulation}

The author will discuss the problems of this paper is as follows:

1. What is the sense of character education?

2. To what extent the importance of character education?

3. What is the role of teachers in character education?

\section{Writing purpose}

From the above problems the author has the following objectives:

1. Know and explain the meaning of character education

2. Know and explain the importance of character education for students

3. Know and identify what are the role of teachers in character education

\section{Character Education Guidelines}

\section{Discussion}

Character Education Guidelines yaiutu a business concept that is earnest in achieving optimal results, the concept emphasizes the high standards (hight standard). Such as hard work, discipline, thought and iklash in accordance with what is expected. "Eight step that needs to be considered in pendidiakan character, Understand the nature of character education, sosialisaikan appropriately, create a conducive environment, developing 
infrastructure and learning resources are adequate, discipline learners, select principals mandate, embodied teacher who can digugu and imitated, and involve the entire school community in the success of character education ". Professor Dr. E.Mulyasa, M.Pd Character Education Management (2016: 15)

\section{Character Education traits include:}

1. Stresses any action based on the normative values. Protege respect existing norms.

2. Build self-confidence, so that students become private firm establishment and is not afraid of new situations.

3. Autonomy, students appreciate and practice the rules of the outside to be a personal value, and

4. Firmness meaningful durability protégé in realizing what is considered good and loyalty (faithfulness) as the basis of respect for the commitments that have ". FW Foerster, (1869-1966)

According to the Ministry of Education and Culture, there are 18 values that must be inserted in the educational process in Indonesia. Among others :

1. Religious,

2. Honest,

3. Tolerance,

4. Discipline,

5. Hard worker,

6. Creative,

7. Independent,

8. Democratic,

9. Curiosity,

10. The national spirit,

11. Love the homeland,

12. Appreciating the achievements,

13. Friendly / communicative,

14. Love peace,

15. Likes to read,

16. Care for the environment,

17. Social Care, and

18. Responsibility.

Character education is a process of forming the character itself is always a positive impact on the development of the students on the emotional, spiritual and personality of a person, the character education is a key part of building a strong personal dedicated. Efforts to maximize the implementation of character education should run as a strategy of strengthening its implementation such as: strengthening the implementation of character education guides, it accommodates institutions that already implement character education and strengthen existingactivities in school.

Character Education is very important to establish a strong personal identity as a mirror of the Nation. The Character Education by experts as follows:

1. "Education pillared to Cipta Rasa and Karsa". Ki Hajar Dewantara

2. "There is no nation-building without character-building." (It will not be possible to build a country that character education is not built). Indonesia's first president Soekarno, Ir

3. "education without character" (education without character). Mahatma Gandhi

4. "Intelligence plus character ... that is the goal of true education" (Intelligence plus the ultimate goal of true education). Dr. Martin Luther King

5. "To educate a person in mind and not in morals is to educate a menace to society" (Educating a person in the aspect of intelligence and not the moral aspect is mara-hazard threat to the public). Theodore Roosevelt

6. "character is a way of thinking and behaving that is characteristic of each individual to live and work together, both within the family, community, nation and country". Prof. Suyanto Ph.D

The different perspectives according to the expert Character Education grown today are:

1. First, given that the national character education stands alone as a subject.

2. Secondly, given the national character education is integrated in the subjects of civics, religious education, and other relevant subjects.

3. The third opinion, national character education integrated into all subjects. 
Reference of the Character Education follows below:

1. Attitude (attitudes),

2. Behavior (behaviors),

3. Motivation (motivations), and

4. Skills (skills).

According Nucci \& Narvaes (2008), moral attitude is a determinant factor, as a determinant of character formation and is an indicator of character such as:

1. Personal improvement is an individual who has a personality that is firm against the rules internalized in him. Thus, he was not so easily swayed by the influence of the social environment which he considers incompatible with the internalized rules. The personality traits in contemporary termed as integrity. Individuals who have high integrity of the values and rules that he would not stand for immoral practices. For example, an individual who upholds the values of his religion will not be affected by the social environment for cheating, manipulation and corruption.

2. Social skills; which has a high social sensitivity so as to give priority to the interests of other people, as shown by the harmonious social relations in every universal values or rules will certainly drive people to maintain good relations with others. For example, individuals who are religious will definitely do good to others or the interests of the ummah.

3. Comprehensive problem solving; namely the extent to which people can resolve conflicts dilemma between the influence of social environment that does not conform with the values or rules with his personal integrity on the value or the rule, meaning that people have an understanding of the actions of others (perspective) that deviate but individuals are still based on the decision as actions the values or rules that have been internalized in him. For example, a student who does not want to follow her friends cheating when not supervised by the teacher because he still upholding the values or rules in force despite the fact that he was able to understand the cause of the behavior of his friends are cheating, flexibility in thinking and understanding in judging an act true or false.

Moral education is one of the characteristics of religion Character Education

According to Silberman (2005), states that the human traits that are religious:

1. Be able to understand God and carry out all his teaching. In this element, people who are required to understand the power of God and practice all the teachings in everyday life.

2. Understand the meaning of self. Man who professed to have an understanding of the nature of the self, life purpose, potential and influence of religious teachings on the process of identity formation. For example, as a Muslim he knows that his purpose in life is simply to serve God Almighty, has potential as a fellow Muslim brotherhood and teachings of Islam as an identity maketh himself.

3. Believing and maintain relationships with other creatures of God's creation and the universe. As a religious man then we are obliged to establish a good relationship with others and the universe.

4. Confidence in the future, namely the belief that must be owned by a religious man of the future life, life after life in the world, such as death, the grave, the Day of Judgment, heaven and hell. Therefore, a religious man who makes life in this world as an investment in the future life of life hereafter.

\section{Teachers Role in Building Character Education}

According to Berkowitz \& Bier (2003). They stated that the application of moral character education influenced the increase in student motivation in achievement. Even classes that comprehensively engaged in character education showed a drastic reduction in negative student behaviors that can hinder academic success. This is due to one of the goals of character education is to develop the personality of integrity to values or rules. When people have integrity then he will have confidence in the potential (self-efficacy) to face barriers to learning.

Character Education of which relate to cognitive skills in research Narvaes (2006).Participants protégé that leads to character education will be like;

1. It's easy to understand the situation accurately moral character and values of run rules are internalized

2. Having a tool or method to solve the problem of complex moral character,

3. Stay focused on academic tasks and motivated to overcome the barriers to learning.

4. Able to prioritize the objectives for the development of potential ethical and social empowerment, therefore, the forward participated Countries emphasize character education as soft-skills.

Teachers as a source of Character Education

Figure example of a Teachers

The teachers in upholding the value of rules that is absolutely necessary in building the character of 
Education. Figure exemplary educators in accordance with the philosophy expressed by Ki Hadjar Dewantara, namely "ngarso ing sung tulodho" (a teacher should be able to provide exemplary attitude and action), the teacher is a figure digugu and imitated (adhered to and emulated his actions).

\section{Recommend}

Teachers should recommend and prepare effective teaching based on those in the general purpose school, general purpose subjects, skills, attitudes and interests of the students, the curriculum and learning techniques in the short term.

\section{Plan}

Teachers should be able to plan for decision making in preparation for teaching and developed by teachers. According to Ornstein (1990: 465-466) as the decision will be influenced by two areas:

1. Knowledge of teachers to the field of study (subject matter knowledge) which emphasizes organization and presentation materials, learners' knowledge of understanding of the material and knowledge about teaching the material.

2. Knowledge of teachers to the system of action (action system knowledge), which emphasizes the teacher's activities, such as mengdiagnosis, categorize organize, and evaluate students, and implement learning activities and learning experiences.

\section{Developing Curriculum}

Teachers should be able elicits curriculum in class, attempting to translate, describe and mentransformasikannilai-value contained in the curriculum to learners, because the teacher's task is not only to transfer knowledge (transfer of knowledge), namely membelajarkana children to be able to think integral and comprehensive, to achieve competence tough character education. Prof. E. Mulyasa (2016: 100).

\section{Gait Teacher to parse the complex problems of education system following Characteristics:}

1. An all-associated elements

2. The elements paced change and adjust to each other

3. Establishment of the existence of a new pattern / typical

4. The presence of elements and new subsystems

5. The existence of the elements of a new linear dynamics

6. There are elements of experiments, games, renewal

7. The existence of the characteristics of the additional behavior / collective

8. The existence of elements of the variation and the new dynamics that constantly

9. The existence of similarities and differences that lasts: partially fused, partially dead/ broken and beyond

10. Non-linear existence and Byfurction dinamyc. According to Achmad Sanusi (2016; 220-221)

Behavior that is based on the values of character educationIn the words of a classic, often stated that mebudaykan character is a process that must be done protégé, because it must seek the natural into the cultural. As this brings us back to the skills that have been put forward which includes the cognitive, affective, psychomotor, confident, Managerial. Here note the picture and illustrations

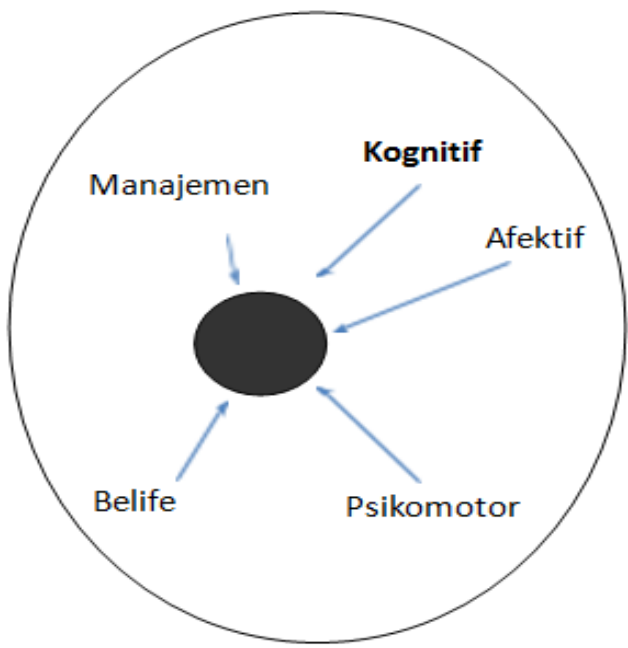

Figure 1.Character of Education Culture 


\section{Conclusion}

1. Character education is a system of cultivation of character values to the students which include, knowledge, awareness, willingness, as well as actions to implement these values. social skills (social skills), personal development (personal improvement) and solving the problem in a comprehensive manner (comprehensive problem solving). Character education can be defined as "the deliberate use of all dimensions of school life to foster optimal character development". In all components of character education should be involved.

2. The process of learning, assessment, subjects, school management, the implementation of the instructional activities, extra curricular activities, facilities and infrastructure, pembiayaanya, work ethic, all components of the school community and the environment. as one entity in character education providers.

3. The character education should be continuous and sustained. Synergies in all its elements will create a formidable character education. like wise words following, "There is no individual success, that there is a collective success".

\section{Bibliography}

[1]. Mulyasa, E. (2016). ManajemenPendidikanKarakter. BumiAksara, PT. Jakarta, Sinar Grafika offset

[2]. Berkowitz, M., \& Bier, M. (2003). What works in character education. Presentation at the Character Education Partnership National Forum.Washington, DC

[3]. Bohlin, Karen, E. (2005). Teaching Character Education through Literature. New York: Routledge Falmer.

[4]. Sutarman, Salim, Agus (2017) Implementation of Quality Management at the National School Curriculum Standard Referring to the Total Quality Control Management (TQM). National Juranl Rausyan Fikri, 1386- 1393, UniversitasMuhammadiyahTangerang.

[5]. Mares, M. L., \& Woodard, E H. (2005). Positive effects of television on children's social interactions: A meta-analysis. Media Psychology, 7, 301-322.

[6]. Nucci, L.P., and Narvaez, D. (2008). Handbook of Moral and Character Education. New York: Routledge.

[7]. Wulandari, Primatia Yogi. (2010). Kids Character = Character TV, The Role of Mass Media in Children Character Formation. Papers for the Indonesian Psychological Association (HIMPSI) East Java. Surabaya: Faculty of Psychology, University of Airlangga.

[8]. Achmad Sanusi. (2016). Education untu Wisdom; Mempetimbankan back system values, learning and intelligence. Editor Irianto, yosal. Bandung, Nuance Cendikia

\section{About the Author}

[9]. Sutarman Born in Bandung, May 10, 1964 Educational Candidate of Doctor in Uninus S3, S2 Master of Management STIMA IMMI, S1 UNJANI Industrial of Engineering and STMIK Triguna UtamaInformatics of Engineering, Lecturer Post Graduate STIE ISM and S1 STMIKTriguna Utama, STKIP ARRAHMANIYAH

[10]. Ahmad Lahir di Lhoksukon Aceh 12 Desember 1971 Educational Candidate of Doctor in Borobudur Univercity S3, Universitas Timbul Nusantara S2 Magister Manajemen, STAIN Malikussaleh S1 Filsouf Religios, Lecturer in MalikussalehSTAIN,Chairmain of STIKES Darussalam

[11]. Haryono Edi Hermawan Born in Bandung, April 6, 1960 S1. STT PELITA NATION Information Engineering, S1. And STIE PELITA NATIONS Management, MASTER MANAGEMENT STIMA IMMI S2, S3 Pasundan University Human Resource Management, Post Graduate Lecturer STIE ISM 